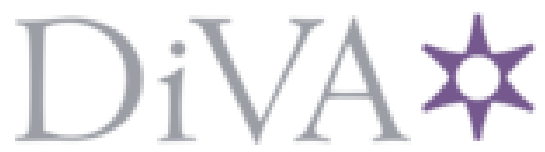

http://www.diva-portal.org

\title{
Postprint
}

This is the accepted version of a paper published in International Journal of Entrepreneurial Behaviour \& Research. This paper has been peer-reviewed but does not include the final publisher proof-corrections or journal pagination.

Citation for the original published paper (version of record):

Brunninge, O., Nordqvist, M. (2004)

Ownership Structure, Board Composition and Entrepreneurship: Evidence from Family Firms and Venture-Capital Backed Firms.

International Journal of Entrepreneurial Behaviour \& Research, 10(1/2): 85-105

Access to the published version may require subscription.

N.B. When citing this work, cite the original published paper.

Permanent link to this version:

http://urn.kb.se/resolve?urn=urn:nbn:se:hj:diva-1871 
Brunninge, O. and Nordqvist, M. (2004). Ownership structure, board composition and entrepreneurship. Evidence from family-firms and venture capital-backed firms. International Journal of Entrepreneurial Behavior and Research, 10(1/2), 85-105.

\section{Ownership structure, board composition and}

\section{entrepreneurship}

Evidence from family-firms and venture capital-backed firms

\section{Olof Brunninge}

Jönköping International Business School

P.O Box 1026

SE- 55111 Jönköping

Sweden

Phone +46733826107

Olof.Brunninge@ju.se

\section{Mattias Nordqvist}

Jönköping International Business School

P.O Box 1026

SE- 55111 Jönköping

Sweden

Phone +46 36101853

Mattias.Nordqvist@ju.se 


\title{
Ownership structure, board composition and entrepreneurship
}

\author{
Evidence from family firms and venture-capital-backed firms
}

\author{
by Olof Brunninge and Mattias Nordqvist
}

\begin{abstract}
The purpose of this article is to investigate how ownership structure, especially family and/or venture-capital involvement, as well as entrepreneurial activities, defined as strategic change and renewal, help explain the involvement of independent members on boards of directors. The CEOs of 2,455 small and medium-sized, private enterprises from practically all industries were contacted in a telephone survey, resulting in an exceptionally high response rate. The findings reveal that family firms are more reluctant to involve independent directors on their boards than non-family firms that presence of venture capitalists increases the frequency of independent board members and that ownership has an impact on board roles. The results do not support the hypothesised relationship that independent directors enhance entrepreneurial activities. One implication of our study is that the often-argued-for strategic contribution of outsiders to the boards in family firms may be overemphasised. Another implication is that family firms that choose to acquire additional capital should be aware that this could result in a change in the board composition and the loss of control of the business. However, new and external owners' inclusion on the board seems to be negotiable since there are also venture capitalists that do not insist on board representation.
\end{abstract}

\section{Introduction}

Boards of directors can play an important role in the governance of firms. However, while possible contributions of boards in the development of large, listed companies often get much attention in both media and research, boards of directors in small- and medium-sized enterprises (SMEs) generally do not. Apart from size, the major dimension that distinguishes these firms from their larger counterparts is the ownership structure. We therefore, know little about the role boards of directors play in entrepreneurial activities in family firms, which constitute the major part of SMEs in most parts of the world (Westhead and Cowling, 1999) and in venture-capital backed firms that also represent an important part of SMEs world-wide (Mason and Harrison, 1999; Zider, 1998). In this article, we look into how ownership structure and entrepreneurship can help to explain board composition and activity in SMEs. More closely, our purpose is to investigate how ownership structure, specifically family and/or venture capital involvement, as well as entrepreneurial activities, defined as strategic renewal and change, help explain the involvement of independent members on boards of directors.

Encouraging entrepreneurial activities is important in all business firms (Stopford and BadenFuller, 1994; Shane and Venkataraman, 2000) and at the level of business firms, corporate entrepreneurship is a concept that is often used to refer to entrepreneurship in established mature firms (Burgelman, 1983; Guth and Ginsberg, 1990; Stopford and Baden-Fuller, 1994). One stream in this literature is concerned with entrepreneurship as strategic renewal and change of an organisation. Typically, these activities include the transformation of the organisation through renewal of the key ideas, products and services on which it is built (Guth and Ginsberg, 1990) and activities classified as risk-taking, proactive and innovative (Covin and Slevin, 1989). We regard other conceptualisations of entrepreneurship in established firms, such as internal business venturing (Burgelman, 1983), entrepreneurial management (Stevenson and Jarillo, 1990), entrepreneurial orientation (Lumpkin and Dess, 1996), or frame breaking, industry wide 
change (Schumpeter, 1934) as relevant also. In this article, however, we define entrepreneurship as strategic renewal and change.

In mainstream board research, focus has been on the effects of different board attributes, such as composition, size, structure and working style on different performance variables (Forbes and Milliken, 1999; Daily and Dalton, 1993; Gabrielsson and Winlund, 2000; Zahra and Pearce, 1989) rather than on entrepreneurial activities. Moreover, a problem with this research is that the findings have been ambiguous and sometimes not significant (Huse, 1998). Among the most frequently used independent variables is board demography. The assumption underlying demography-performance research is that an optimal board structure will affect firm performance in a positive way such as increasing the entrepreneurial capacity. However, even if board composition is often used as an independent variable in order to explain performance, we have little knowledge concerning the determinants of board composition. Thus, a variable is used that is still insufficiently understood. It is, therefore, not enough to find out whether a certain kind of board demography is associated with superior performance. Rather, we first have to understand board demography as such. Normative advice regarding the involvement of independent board members is of little use if we do not know which firms tend to involve independent directors and which ones refrain from doing this. This argument is especially viable in the SME context.

In the coming parts of the article we will first present and discuss relevant literature concerning the role of boards, reasons for involving independent board members and possible linkages between ownership, entrepreneurial activities and board composition. Earlier literature in this area is scattered and inconsistent, which is a typical characteristic of an under-researched area. Therefore, we aim at integrating this body of literature and formulating and testing hypotheses based on a collected analysis of earlier literature. Our main emphasis will lie on literature considering the impact of family ownership, venture capital backing, and entrepreneurial activities on board composition. Previous research suggests that these factors are important for understanding the inclusion of independent directors on boards. Emanating from earlier literature, hypotheses are presented and subsequently tested on empirical data. In the final section of the article the findings of the study are summarised, conclusions are drawn, and questions for further research are outlined.

This research contributes new insights into the understanding of board composition and its relation to entrepreneurial activities. It also contributes knowledge on how different typical ownership constellations in SMEs affect the propensity to include independent directors on the board. Both these aspects have not been much researched in the previous literature, but will help us to get a better knowledge on how boards are composed. Especially, our research contributes to the field of family firms.

\section{Entrepreneurship as strategic renewal and change}

Entrepreneurship as strategic renewal and change is one of several notions of corporate entrepreneurship, i.e. entrepreneurial activities in established companies. Common to all type of corporate entrepreneurship is that it can improve competitive positioning and transform companies, their markets and industries as the result of exploitation of new business opportunities (Covin and Miles, 1999). Strategic renewal of a company is a pervasive activity that is related to the rejuvenation and transformation of key strategic ideas on which the company is built (Stopford and Baden-Fuller, 1994). Strategic renewal is the result of entrepreneurial activities that are innovative, proactive and risk-taking (Covin and Slevin, 1989). Stopford and Baden-Fuller (1994) further argue that these activities can be initiated and carried out both by individuals, such as a single board member in this study, or by groups of individuals, such as the board as a group in our study. In this context, strategic renewal is deliberate and significant repositioning actions that include issues such as introduction of new products, market processes and technologies (Covin and Miles, 1999). In this article, this means 
that companies characterised by strategic renewal are engaged in entrepreneurial activities that trigger an active orientation towards identifying and pursuing opportunities and changing the established way of doing business. In a subsequent section, we will return to this and more systematically outline the relationship between the board and entrepreneurship as strategic renewal and change in family firms and venture capital backed firms. First, however, we will discuss board roles and board composition in these types of firms.

\section{Board roles}

To understand why boards are composed differently it is crucial to be aware of the variety of roles a board can have. Boards with a "passive role" (Huse, 1995), merely fulfil legal requirements to have a board as for instance owner-managers may have a desire to avoid interference from board members (Mace, 1971). The "control role" uses agency theory (Jensen and Meckling, 1976) as a point of departure and controls management on behalf of the owners (Forbes and Milliken, 1999). Especially in large firms, the control role becomes important (Zahra and Pearce, 1989). In an entrepreneurship context, however, the "service role" is the most interesting one. It refers primarily to the board as a provider of advice and expertise to top managers (Forbes and Milliken, 1999; Zahra and Pearce, 1989). Such assistance is of specific importance for carrying out entrepreneurial activities where board members can help managers in accomplishing such activities. In such a situation, boards can also be used to link the company with important stakeholders in its environment (Borch and Huse, 1993; Fiegener et al., 2000), meaning that board members create and maintain a network for the firm. This network enhances the organisation's boundaries since representatives of external stakeholders are included in the board, and board members draw upon their personal networks to establish contacts to actors in the firm's environment. As a consequence, it becomes easier for the firm to control important resources it does not possess of its own (Pfeffer and Salancik, 1978). Such resource acquisition is critical in entrepreneurial activities (Stevenson and Gumpert, 1985).

\section{Board composition and board roles in family firms}

There are a great variety of family firm definitions. In this article, we define family firms as those companies that are both perceived by the respondent (owner-manager) as a family business, and that have both ownership (majority of voting shares) and management (CEO) control within one family (Westhead et al., 1996; Samuelsson, 1999). This definition covers the importance of ownership, which is one of the key features in the present article. The perception as a family firm indicates an emotional bond to the firm that is likely to influence the willingness to let independent directors enter the board.

We want to capture family firms that open up their boards to influences in entrepreneurial activities that go beyond the employee and family groups. Several authors have recently strongly argued for the importance of an active board with independent board members in family firms (e.g. Gersick et al., 1997; Neubauer and Lank, 1998; Huse, 2000). Scholars have, however, also pointed out that family members, relatives and/or close friends to the family dominate the board composition in family firms. Fiegener et al. (2000), for instance, found that SMEs where the CEO and related family have dominant ownership tended to have few independent board members.

Therefore, calls for more studies on board composition and board roles in family firms in order to better understand the presence or absence of outside directors are increasing (Ward, 1991; Huse, 1998). Broadly, the board of directors in family firms can take on the same roles as in non-family firms. Additionally, some authors point out the family issues role i.e. supporting in generational succession, co-ordinating the family and the firm and resolving conflicts (Dyer, 1986; Mueller, 1988; Ward, 1991; Whisler, 1988).

Regarding the composition of the family firm board of directors, the existing research has mainly been occupied with the relation between the number of outside directors on the board 
and the family firm performance. Danco and Jonovic (1981) argued for a board partly composed of outside directors in order to improve the strategic direction of the firm. The outside directors are considered important in assisting management with advice, expertise and external influences (c.f. Fiegener et al., 2000; Huse, 2000). Within the same tradition we find contributions from Ward $(1988,1991)$. Ward's (1991) main point is that family firms should make the best use out of a board, which for him means including outside directors, since most family firms are required to have a board according to the law.

Ward and Handy (1988) found support when hypothesising that a board composed by mainly outside directors is valuable for the family firm. Similarly, Schwartz and Barnes (1991) found in their study of CEOs' attitudes towards independent directors, that it is perceived as strongly rewarding for the family firm with independent directors on the board. Moreover, they conclude that the more independent people on the board, the better and the more family members on the board the worse. Independent directors were found to be most helpful in providing unbiased views, forcing management accountability and establishing networks of contacts. Moreover, Schwartz and Barnes (1991) stress the importance of a careful selection of independent/outside directors, which is a point that also Johannisson and Huse (2000) strongly make. The background and competence of independent directors are essential if they are to contribute positively to the family firm (Johannisson and Huse, 2000).

Researchers have also shown that boards composed of outside directors give valuable contributions in different crucial situations for the family firm. For instance, the board's role in the planning of CEO succession (Danco and Jonovic, 1981; Ward, 1991), as a bridge between the family logic and the business logic (Ward, 1991; Harris, 1989), and as a resource when the family management do not have time or competence to alone develop their firm have been highlighted (Mueller, 1988). Some commentators have also pointed out the outside director's role as a mediator in family related conflicts (Mueller, 1988; Whisler, 1988), whereas others strongly advise against getting involved in family issues (Ward, 1991; Schwartz and Barnes, 1991). To conclude, there are many findings that suggest that once included, outside directors do contribute to and play a valuable role in the boards of family firms.

Nevertheless, research has also revealed negative aspects of boards composed of outside directors. Jonovic (1989, p. 132), for instance, argued:

Managing a board of directors is a complex task, requiring attention, preparation, careful planning and time. These are, generally, the commodities in shortest supply in the family business.

In a similar vein, Ford (1988) suggested that outside directors often lack knowledge about the firm's resources and competences as well as about its environment. He also argued that outside directors often experience that owner/managers are not available for counselling and/or unwilling to let go of control. Empirically, Ford (1988) found in his sample of American privately held firms that outside directors were neither as influential nor as effective as their advocates claimed. Instead, he concludes that outside directors reduced the total influence of the board. In their study of board practices in Italy, Corbetta and Tomaselli (1996) found that even if a board with outside directors may be considered useful, few firms actually have a board composition with outside directors. Ward (1991) discussed reasons for the lack of outside directors in many family firm boards. He argued that the main reasons are that owners tend to be afraid of losing control, disbelieve that the outside directors understand the firm's competitive situation, are afraid of opening up for new, external ideas and viewpoints and finally that they think that board work steals a lot of time from more urgent, operational issues.

To sum up, we conclude that there are many reasons for how and why a family firm may benefit from an active board with independent directors. But we also have reasons to assume that board 
work remains passive in many family firms and that many do not have a board with independent directors. Typically, the board does not become active until the family firm eventually includes independent directors. Based on this review of earlier literature we therefore state the following hypotheses:

H1. Non-family firms are more likely to have independent board members than family firms.

H2. Family firms with independent directors have a more active board than family firms without independent directors.

\section{Board composition and board roles in venture capital-backed firms}

The start-up of new firms, or the renewal of old ones, is often related to substantial financial commitment. Venture capital is often referred to as an increasingly important form of financial investment, and the amount of venture-capital backed firms is growing in most parts of the world (Ang, 1991; Bruton et al., 1997). A venture capitalist is here defined as a firm that provides capital and takes on a temporary ownership engagement in another firm. Venture capital backed firms we therefore regard as companies with any ownership control by venture capitalists, regardless of the size of their stake. In this article, a venture capital-backed family firm is any firm that meets the requirements of the family firm definition above, and that has less than 50 per cent of ownership controlled by a venture capitalist. This means that a firm with more than 50 per cent ownership by venture capitalists ceases to be considered as a family firm since in this case the venture capitalist is able to control decision making more or less independently of other owners.

In the venture capital-backed firm, the professional investor takes on an ownership stake in the business. In order to control and monitor this investment, the venture capitalist typically serves on the board of directors of the firm (Rosenstein, 1988; Rosenstein et al., 1993; Bruton et al., 1997; Fried et al., 1998). The board member representing the venture capitalist directly represents a major stockholder and thus it should be expected that he/she have considerable power and influence in relation to the executive management. Indeed, this should be the case even if the ownership majority remains in the hands of an owner-manager, such as in family firms.

Prior research into board composition and board roles of venture capital-backed firms has traditionally focused on the board's involvement in strategy, the size of the board and the outsider ratio (Fried et al., 1998). In his study of small high-technology firms, financed by large venture capital partnerships, Rosenstein (1988) found that the board was actively involved in strategy formulation as well as in monitoring its implementation. Furthermore, he found that the board was small in size and dominated by outsiders, with frequent meetings and a formal agenda. The findings that boards of venture capital-backed firms tend to be small boards that have high outsider ratio have been confirmed in subsequent studies (Rosenstein et al., 1993; Fried et al., 1998). Rosenstein et al. (1993) and Fried et al. (1998) also revealed that the boards increase in size as the firm grows and Gabrielsson and Huse (2002) found that boards in venture capital-backed businesses are more active than in other firms. The boards in Rosenstein et al.'s sample of high-tech enterprises also tended to continue being dominated by venture capitalists or their representatives, when the firm grew. The board's involvement in monitoring performance, strategy formulation and the implementation of strategic decisions is considerable in venture capital backed firms (Rosenstein et al., 1993; Lerner, 1995; Bruton et al., 1997; Fried et al., 1998). This is especially true in times of strategic renewal and change. Here, studies have shown that the board is perceived as particularly active and useful (Rosenstein et al., 1993; Lerner, 1995; Bruton et al., 1997).

Fried et al. (1998) also found that boards of venture capital-backed firms are more involved in strategy formulation and evaluation when compare to boards where the directors do not control 
a large part of the ownership. In the same vein, and by applying agency theory, Johnson et al. (1993) showed a positive relationship between the extent to which the directors of the board had an ownership stake and their involvement in restructuring the firm. Accordingly, agency theorists argue that venture capitalists should be active board members since they have a considerable ownership stake (Fried et al., 1998). However, somewhat differently, Rosenstein et al. (1993) found that outsiders on the board without a relation to the venture capitalist had a similar role and were as useful as the average venture capitalist on the board. For the reasons stated in the preceding sections, we believe that family ownership and venture capital backing are two important factors to consider when trying to explain the existence of independent directors on boards. Family businesses should, according to earlier literature, be more reluctant than non-family businesses to include independent directors on their boards, while the presence of venture capital should increase the likelihood of independent directors in both family and non-family firms. There is no earlier research on the composition of boards in family firms with venture capital backing. Drawing attention to this neglected group of firms is thus an important part of this article. Including this group of firms, our discussion leads to four categories of firms, depending on the existence of family ownership and venture capital backing as shown in Figure 1.

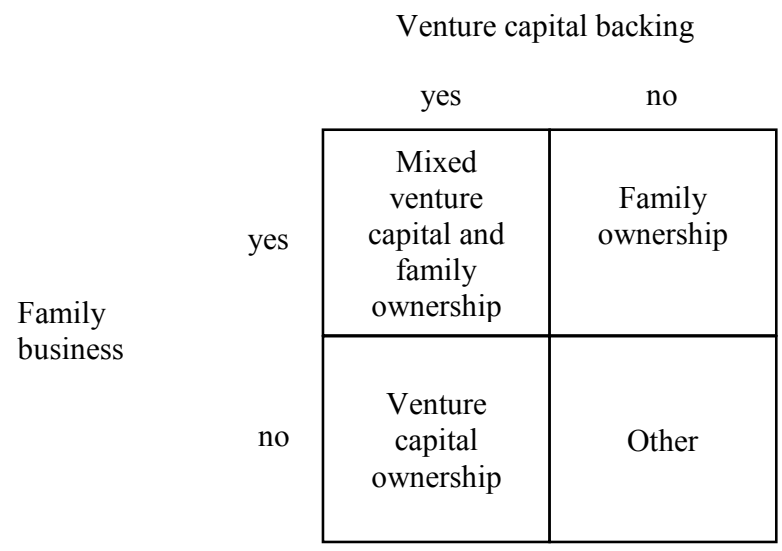

Figure 1. Four categories of firms according to ownership

From our literature review we can thus derive the following hypotheses:

H3. Venture capital backed firms are more likely to have independent directors than firms that are not venture capital backed.

H4. Family firms with venture capital backing are more likely to have independent directors than family firms without venture capital backing.

H5. Non-family firms with venture capital backing are more likely to have independent directors than non-family firms without venture capital backing.

H6. Venture capital backed firms have a more active board than firms that are not venture capital backed. 


\section{The board and entrepreneurship}

Entrepreneurship constitutes a challenge for any firm. Companies facing ever-changing environments have to renew themselves in order to avoid the risk of strategic drift (Johnson, 1988). Dess et al. (1997) see a need for organisations to engage in entrepreneurial activities in the sense that they have to take an active stance in pursuing opportunities and taking risks. This includes action and change as suggested by Miles and Snow (1978) in their conceptualisation of prospector firms. However, entrepreneurial activities are not an easy undertaking. As Pettigrew and Whipp (1991) state, firms both need the capacity to interpret the competitive forces in their environment and the competence to mobilise and manage the resources necessary to respond to the competitive challenges they have identified. Therefore, entrepreneurial activities put demands on both the internal management of the change process and on monitoring the environment. Concerning the latter aspect, change requires environmental assessment, collection of information, and management of relationships with key external stakeholders. Moreover, Stevenson and Gumpert (1985) emphasise the crucial role of resource acquisition for entrepreneurial activities.

Strategic renewal of a company puts new demands on a firm's entrepreneurial capacity and can work as a trigger for change of the board's role. The need for entrepreneurial capacity and competence can be fulfilled in various ways. In some cases, management may believe that it has alone the necessary resources to handle successfully the strategic renewal and to meet the new requirements awaiting the firm as a result of the change. If this is not the case, resources have to be acquired elsewhere. One interesting option in this respect is an enhancement of the board's service role. Regarding entrepreneurial capacity, the board can play an important role in dealing with a complex and changing environment, for example by being used for networking with important stakeholders (Borch and Huse, 1993). In particular, independent directors may provide managers with novel information and opportunities that are not at their disposal otherwise (Daily and Dalton, 1993; Fiegener et al., 2000). This role goes beyond that of improving entrepreneurial capacity as also competence to manage the actual renewal process is raised. The board becomes a bridge between external and internal stakeholders (Huse, 1998) and helps to mobilise resources the firm itself does not possess (Pfeffer and Salancik, 1978). Directors can also help legitimise the company vis-à-vis stakeholders that are important during or after the process of renewal (Conger et al., 1998).

We therefore, argue that entrepreneurial activities increase the need to include independent directors on the board. Even though for instance family firms may have refrained from using independent board members in order to avoid non-family members' interference in company affairs, strategic renewal may be a reason to re-think this standpoint. The decision to finally include independent directors and to change the composition, is then often related to the event that the family firm is faced with a situation of strategic renewal, generational succession, organisational crisis or that the owner family experiences that their own competence is not enough for the entrepreneurial development of the firm (Gersick et al., 1997; Larsson and Melin, 1999). Entrepreneurial activities are often characterised by the acquisition of new resources and pursuit of new opportunities. Instead of being discouraged by lack of resources, entrepreneurial leaders strive to pursue opportunities and acquire resources that are currently not at their disposal (Stevenson and Gumpert, 1985). This can for instance be done with the help of independent directors, spanning the boundaries of the firm (Pfeffer and Salancik, 1978). A change of the board role, by adding independent directors can thus be a means to carry out entrepreneurial activities.

While we believe that entrepreneurial activities lead firms to take in independent directors on the board, the reverse relationship may also apply. Independent directors can make boards more proactive and moreover, contribute with additional information and their personal expertise (Pearce and Zahra, 1991). They may thus, be important catalysts for entrepreneurial activities, triggering new business activities and seeing opportunities that are still unperceived by management. Directors with extensive industrial knowledge are especially well suited to engage 
in the entrepreneurial development of a firm (Jonnergaård and Svensson, 1995). Consequently, a firm might increase the industrial knowledge at its disposal by adding independent members to the board. Such an industrially oriented board is then more suitable to initiate strategic renewal. To sum up, we expect entrepreneurial activities and the ratio of independent directors to affect each other positively in both directions. A segmentation of our database will allow seeing if the expected relationship holds for all ownership regimes or if there are differences between family business/non-family businesses or venture capital backed/non venture capital backed firms. We can therefore, hypothesise that:

H7a. In family firms without venture capital involvement the ratio of independent directors is positively associated with entrepreneurial activities.

H7b. In family firms with venture capital involvement the ratio of independent directors is positively associated with entrepreneurial activities.

H7c. In non-family firms without venture capital involvement the ratio of independent directors is positively associated with entrepreneurial activities.

H7d. In non-family firms with venture capital involvement the ratio of independent directors is positively associated with entrepreneurial activities.

\section{Method}

\section{Sample}

The sample used for our analyses originally consisted of 2,455 Swedish private enterprises from practically all industries. The only major industry that was excluded was wholesale trade. It was stratified according to three variables:

(1) size (50 per cent each from 10-49 and 50-249 employees, i.e. the European Union definition of small- and medium-sized companies);

(2) independence (one third each of completely independent, i.e. not members of a business group, members of business groups with less than 250 employees, and members of business groups with 250 employees and more. For calculating the size of the business group, the sum of employees at the mother company and its subsidiaries has been calculated); and

(3) industries (26 per cent manufacturing, 23 per cent retailing, 21 per cent professional services, 12 per cent transport and communication, 8 per cent trade and hospitality, 4 per cent health care and social services, 2 per cent financial activities and 4 per cent other services).

Data were collected through telephone interviews with CEOs between March 1997 and August 1997, resulting in a response rate of 82.9 per cent. The telephone interviews were followed up with mail questionnaires. However, data collected via a postal survey is used for this article. Our analyses are based on half of the responses from the original sample, i.e. 1,026 cases, keeping the other half for possible confirmatory analyses. Sample firm cases are distributed across the four ownership categories (Figure 2).

The data for this study are drawn from a database, which was originally collected for a research program at Jönköping International Business School, examining entrepreneurship in different organisational contexts. Governance and change were important features in the set of variables used. Thus, there was a collection of variables that could be used to examine the research questions in this article, although, having to rely on secondary data, we could not affect the stratification of the sample. Also, our opportunity to operationalise different concepts was limited. This is also reflected in the use of definitions of core concepts. However, all definitions 
used have been applied in earlier empirical research and have reasonable backing in the relevant literature discussed and presented above.

\section{Variables}

Previous research on family businesses has shown that the definition of family business is critical for research outcomes. Results have been strongly associated with the definition used (Westhead et al., 1996). For the present study family businesses were conceptualised as organisations meeting both of the following criteria:

- The respondent conceived the company as a family business.

- Both ownership and management control of the company or the business group were dominated by one family, meaning that the family controlled more than 50 per cent of the votes in the firm.

Both aspects are included in the definition used by Samuelsson (1999) that also contains some further items.

"Venture capital" backing was simply measured by examining whether any venture capitalists were among the owners of the company.

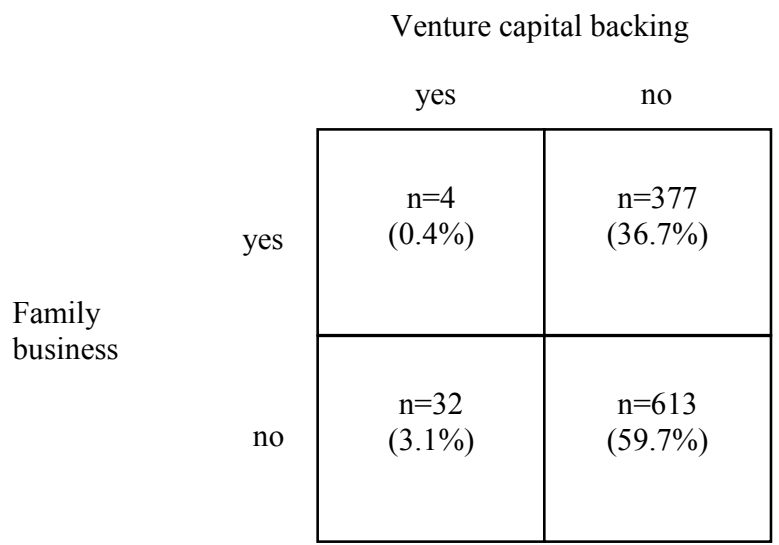

Figure 2. The sample by ownership regime

The ratio of "independent directors" was calculated as the percentage of directors not working for the firm on a daily basis and not belonging to the predominant owner family among board members except for possible union representatives. The reason for not including union representatives in the number of total board members was that our theoretical reasoning is based on the logic owners apply when appointing directors. Since employees appoint union representatives they were not relevant to the discussion in the present article.

The annual "number of board" meetings approximated board activity, assuming that passive boards tend to have few meetings. In cases that more than approximately 12 board meetings were held annually the respondents were asked to indicate the number of meetings where minutes were written.

"Entrepreneurial activities" were measured by an index (Cronbach's alpha 0.69) measured as the sum of eight dichotomous items, each indicating a significant measure representing entrepreneurial activities during the last 12 months. The measures were: 
- starting doing business with a country the company had previously not done business with;

- starting marketing oneself in a new way;

- carrying out a considerable change of the company's organisation;

- carrying out a considerable change in the company's internal operations;

- introducing an important new product or service or in any other way

- substantially changing offerings to customers;

- commencing the development of a new important product, service or similar, which has not yet been introduced;

- carrying out measures in advance that the company otherwise would have been forced to do sooner or later; and

- carrying out changes particularly in order to get ahead of competitors.

All these items offer jointly an operationalisation of entrepreneurial activities that covers renewal in different parts of the organisation. As with all data for the study, the items are secondary data. The reasoning behind is built on a logic trying to grasp a great variety of renewal activities depicted in the literature reviewed above.

\section{Analysis}

The hypotheses stated above were tested in a number of data analyses. As an initial step, differences between firm categories regarding the ratio of independent directors and the activity of boards were examined, using independent two-tailed t-tests (Table I).

H1 states that non-family firms are more likely to have independent directors than family firms. Our analysis shows that this is actually the case as the percentage of independent directors on boards of non-family firms is on average about ten percentage points higher than in family firms. Even though standard deviations show that the independent directors' ratio varies rather much in each group, the difference between groups is significant and confirms our hypothesis. Hence, reluctance to share power with independent members on the board exists in family firms.

Table I. Independent two-tailed $t$-test between family firms and non-family firms

\begin{tabular}{|c|c|c|c|c|c|}
\hline & \multicolumn{2}{|c|}{$\begin{array}{c}\begin{array}{c}\text { Family firms } \\
(n=381)\end{array} \\
\end{array}$} & \multicolumn{2}{|c|}{$\begin{array}{c}\text { Non-family firms } \\
\qquad(n=645)\end{array}$} & \\
\hline Ratio of independent directors & $\begin{array}{c}\text { Mean } \\
0.24\end{array}$ & $\begin{array}{l}\text { S.D. } \\
0.27\end{array}$ & $\begin{array}{c}\text { Mean } \\
0.35\end{array}$ & $\begin{array}{l}\text { S.D. } \\
0.32\end{array}$ & $\begin{array}{l}t \text {-value } \\
5.26^{* * *}\end{array}$ \\
\hline
\end{tabular}

Note: ${ }^{*} \mathrm{p}<0.1 ;{ }^{* *} \mathrm{p}<0.05 ;{ }^{* * *} \mathrm{p}<0.01$

$\mathrm{H} 2$ however, states that once family firms have taken in independent directors, the board will be more active than those lacking independent directors. The subsequent analysis confirms this (Table II).

Table II. Independent two-tailed $t$-test between family firms with independent directors and family firms without independent directors

\begin{tabular}{lccccl} 
& \multicolumn{2}{c}{$\begin{array}{c}\text { Independent directors } \\
(\boldsymbol{n}=\mathbf{2 0 2})\end{array}$} & \multicolumn{3}{c}{ No independent directors } \\
$(\boldsymbol{n}=\mathbf{1 7 9 )}$
\end{tabular}

Note: ${ }^{*} \mathrm{p}<0.1 ;{ }^{* *} \mathrm{p}<0.05 ;{ }^{* * *} \mathrm{p}<0.01$

There is a significant difference in the frequency of board meetings between the two groups of family firms. Board meetings are not very frequent in either of them. However, on average, the 
existence of independent directors adds one board meeting per year. Thus, independent directors tend to increase board activity (Table III).

Table III. Independent two-tailed $t$-test between venture capital-backed firms and not venture capital-backed firms

\begin{tabular}{|c|c|c|c|c|c|}
\hline & \multicolumn{2}{|c|}{$\begin{array}{l}\text { Venture capital-backed } \\
\qquad(n=36)\end{array}$} & \multicolumn{2}{|c|}{$\begin{array}{l}\text { Not venture capital-backed } \\
\qquad(n=990)\end{array}$} & \\
\hline Ratio of independent directors & $\begin{array}{c}\text { Mean } \\
0.44\end{array}$ & $\begin{array}{l}\text { S.D. } \\
0.30\end{array}$ & $\begin{array}{c}\text { Mean } \\
0.31\end{array}$ & $\begin{array}{l}\text { S.D. } \\
0.31\end{array}$ & $\begin{array}{l}t \text {-value } \\
-2.68 * *\end{array}$ \\
\hline
\end{tabular}

Note: ${ }^{*} \mathrm{p}<0.1 ; * * \mathrm{p}<0.05 ;{ }^{* * *} \mathrm{p}<0.01$

As stated in $\mathrm{H} 3$, venture capital backing also has an effect on the ratio of independent directors. Generally, independent board members are not very common in firms in the sample. In venture capital-backed firms the mean ratio of independent board members almost amounts to one half however, if firms do not have venture capitalists among their owners the ratio is significantly lower. Hence, it emerges that venture capitalists insist on board representation when investing in a firm. Still, the majority of venture capital-backed firms have no independent board members. The relationship between the existence of venture capital backing and the ratio of independent directors was also tested for family firms and non-family firms separately as shown in Table IV.

Table IV. Independent two-tailed $t$-test between venture capital-backed family firms and not venture capital-backed family firms

\begin{tabular}{|c|c|c|c|c|c|}
\hline & \multicolumn{2}{|c|}{$\begin{array}{c}\text { Venture capital-backed } \\
\qquad(n=4)\end{array}$} & \multicolumn{2}{|c|}{$\begin{array}{l}\text { Not venture capital-backed } \\
\qquad(n=377)\end{array}$} & \\
\hline Ratio of independent directors & $\begin{array}{c}\text { Mean } \\
0.46\end{array}$ & $\begin{array}{l}\text { S.D. } \\
0.08\end{array}$ & $\begin{array}{c}\text { Mean } \\
0.24\end{array}$ & $\begin{array}{l}\text { S.D. } \\
0.27\end{array}$ & $\begin{array}{l}t \text {-value } \\
-1.62\end{array}$ \\
\hline
\end{tabular}

Note: ${ }^{*} \mathrm{p}<0.1 ; * * \mathrm{p}<0.05 ; * * * \mathrm{p}<0.01$

The mean ratio of independent directors in venture capital backed family firms is approximately the same as for the whole population of firms, while the ratio for family firms without venture capital backing is even lower than for firms in general (Table V). Unfortunately, the number of venture capital backed family firms in the sample is so low (a natural phenomenon) that we do not arrive at any significant results. One can, of course, ask the question if a different operationalisation of venture capital backed family firms had been appropriate and if this had increased the number of firms in this category. Allowing for venture capital-backed family firms to have more than 50 per cent ownership by venture capitalists could have increased the number of cases slightly. However, it is highly doubtful if a firm, where the family is only a minority owner, still allows the family to have considerable influence on business decisions. The significance level for the comparison of means is at 0.106 . Our analysis thus fails to support H4.

Table V. Independent two-tailed $t$-test between venture capital-backed non-family firms and not venture capital-backed non-family firms

\begin{tabular}{lcccccc} 
& \multicolumn{2}{c}{$\begin{array}{c}\text { Venture capital-backed } \\
(\boldsymbol{n}=\mathbf{3 2})\end{array}$} & \multicolumn{3}{c}{$\begin{array}{c}\text { Not venture capital-backed } \\
(\boldsymbol{n}=\mathbf{6 1 3 )}\end{array}$} \\
& Mean & S.D. & Mean & S.D. & $t$-value \\
Ratio of independent directors & 0.44 & 0.32 & 0.34 & 0.32 & $-1.73^{*}$ \\
\hline
\end{tabular}

Note: ${ }^{*} \mathrm{p}<0.1 ;{ }^{* *} \mathrm{p}<0.05 ;{ }^{* * *} \mathrm{p}<0.01$

A similar test for non-family firms with and without venture capital backing confirms our H5 that venture capital backing increases the ratio of independent directors in non-family firms. Here again, independent directors are more common in the cases where venture capitalists are 
among the owners. However, this finding is only significant on a 0.1 -level. The low number of venture capital-backed firms in our sample makes it difficult to achieve significant findings concerning this group of companies (Table VI).

Table VI. Independent two-tailed $t$-test between venture capital-backed firms and not venture capital-backed firms

\begin{tabular}{lcccc} 
& \multicolumn{2}{c}{$\begin{array}{c}\text { Venture capital-backed } \\
(\boldsymbol{n}=\mathbf{3 6 )}\end{array}$} & \multicolumn{2}{c}{$\begin{array}{c}\text { Not venture capital-backed } \\
(\boldsymbol{n}=\mathbf{9 9 0})\end{array}$} \\
\hline $\begin{array}{l}\text { Number of board meetings } \\
\text { annually }\end{array}$ & Mean & S.D. & Mean & S.D. \\
\hline
\end{tabular}

Note: ${ }^{*} \mathrm{p}<0.1 ; * * \mathrm{p}<0.05 ; * * * \mathrm{p}<0.01$

Venture capitalist ownership also has an impact on board activity. The test above gives significant support to H6, showing that board activity conceptualised as the number of annual meetings increases significantly if venture capitalists are among the owners. The high standard deviation shows that frequency of board meetings varies a lot (Table VII).

Table VII. Correlations between ratios of independent directors and degree of entrepreneurial activities for different categories of firms

\begin{tabular}{lccc} 
& Pearson correlation & Sig. (2-tailed) & n \\
\hline Family firms without venture capital & 0.07 & 0.20 & 377 \\
Family firms with venture capital & 0.58 & 0.42 & 4 \\
Non-family firms without venture capital & 0.05 & 0.26 & 613 \\
Non-family firms with venture capital & 0.11 & 0.56 & 32 \\
\hline
\end{tabular}

The second step of our analysis included empirically testing our hypotheses regarding the board of directors and entrepreneurial activities. We proposed that entrepreneurial activities and the ratio of independent directors would be positively related in all ownership classes, experiencing entrepreneurship as strategic renewal increases the ratio of independent directors and independent directors provoke entrepreneurial activities. Our data did not permit us to test the relationship in any particular direction. This could however be an interesting issue for further research on longitudinal data.

The results in this section of the analysis revealed interesting findings. $\mathrm{H} 7 \mathrm{a}$ states that the ratio of independent directors is positively associated with entrepreneurial activities. Our analysis shows virtually no correlation and we find no support for this proposition.

H7b, however, show rather high Pearson's correlation; 0.58 for the same proposed relationship, but in this case for family firms with venture capital. This would suggest some support for the hypothesis. The two-tailed significance test does not, however, let us arrive at any significant results. The reason for this ought to be that the sample is too small to achieve statistically significant results $(n=4)$.

The relationship between the ratio of independent directors and entrepreneurial activities was also tested for non-family firms, without venture capital involvement $(\mathrm{H} 7 \mathrm{c})$. Here the correlation is still rather low, 0.05 , and the suggested positive relationship is again not significant.

In our last hypothesis (H7d), we ran the same analysis for non-family firms that are venture capital backed. The findings show that the correlation is low; 0.11 and that the proposed relationship is not significant. Thus, the hypothesis found no support. 


\section{Discussion}

In this article, we have argued that researchers need a deeper understanding of board demography, before using, for example, board composition as an independent variable. Our aim has been to examine which firms tend to involve independent directors and which do not. The main argument was that ownership and entrepreneurial activities help explain the presence of independent members on the board of directors in firms. We have done this by presenting hypotheses emanating from relevant earlier studies on board composition in family firms and in venture capital-backed firms. For the hypotheses on entrepreneurial activities, we looked at earlier literature, with an emphasis on the board's role in strategic renewal. Our analysis reveals interesting results. The hypothesised relationships in the first section of the paper (ownership structure and independent directors) were generally supported, whereas our hypotheses in the second section (entrepreneurial activities and independent directors) received little to no support.

\section{Independent directors in family firms}

Our findings show that non-family firms are more likely to have independent board members than family firms. This strongly confirms arguments from earlier studies showing that family firms in general do not tend to have independent directors (Gersick et al., 1997; Ward, 1991; Corbetta and Tomaselli, 1996). Hence, although several commentators have pointed out the benefits that independent directors may offer to the family firm, this potential resource remains untapped in most family firms. Moreover, it is also in line with earlier findings that non-family firms are more likely to have independent directors. In these firms, the board can be more of a meeting place and discussion forum for different issues.

In most family firms, the pressure from different ownership and other stakeholder groups is not as strong. Instead the choice to have an active board with independent directors is generally a decision taken by the owner-family. Moreover, we received strong support for our second hypothesis. Family firms with independent directors do have a more active board than those without. Without being able to say much about the actual working style and board task performance (c.f. Gabrielsson and Winlund, 2000) we may assert that this finding supports earlier research stating that once included, independent directors tend to play an active, and often valuable role (Jonovic, 1989; Ward, 1991; Ward and Handy, 1988; Harris, 1989; Mueller, 1988; Schwartz and Barnes, 1991). This is based on the logical assumption that if the board meetings are regularly held, the owners should conceive of them as valuable. However, it should also be pointed out that family firms that do not have an active board might replace this forum with regular family meetings (Gersick et al., 1997; Neubauer and Lank, 1998), which can substitute for some of the tasks generally attributed to the board. Present on these family meetings are typically family members, but possibly also consultants and/or advisors that may play a role similar to that of an independent director on the board.

\section{Independent directors in venture capital-backed firms}

Earlier literature suggested that we should expect it to be more likely that venture capital-backed firms have independent directors than firms without venture capital involvement (H3). This relationship was supported and significant. The finding confirms and gives further support to earlier arguments that the venture capitalists generally prefer to be represented on the board of the firms in which the invest. In the test of the presence of independent directors in venture capital backed family firms and non-family firms (H4) we did not arrive at any significant results. The analysis shows that the ratio of independent directors for family firms without venture capital is lower than for firms in general, which is in line with earlier argumentation. However, the sample for venture capital backed-family firms is too small to draw any further conclusions. Here, more research is clearly needed. Moreover, the empirical analysis gave support for $\mathrm{H} 5$, indicating that venture capital backing actually increases the ratio of independent directors in non-family firms. Thus, the test gives further evidences to the suggestion that independent board members are much more likely in those firms where at least 
one owner is a venture capitalist. As discussed above, this confirms earlier contributions to the literature.

Finally, we hypothesised that venture capital-backed firms should be expected to have a more active board of directors than the firms where no venture capital is involved. The analyses showed that the number of meetings do tend to be higher in venture capital-backed firms. The proposed relationship was strongly supported and we arrived at significant results on the 0.01 level. Interestingly enough, the standard deviation for number of board meetings is much higher in non-venture capital backed firms: 4.25 compared to 1.68 for venture capital backed firms. One explanation for this finding could be that firms with venture capital have a more structured board work with regular meetings, than do firms without venture capital. This is an interesting finding that may indicate that venture capitalists have a tendency to take on a control role as conceptualised in agency theory (Johnson et al., 1993; Fried et al., 1998).

\section{Entrepreneurial activities}

We had originally hypothesised that entrepreneurial activities would be associated with a higher ratio of independent directors, assuming that independent directors might trigger more entrepreneurial activities and that firms might include independent directors in order to facilitate changes they want to undertake. However, the empirical support we found for our hypotheses was very weak. Although entrepreneurial activities and the ratio of independent directors were positively correlated for the companies in all examined ownership categories, the relationship was only weakly significant in one of them, namely non-family firms without venture capital backing. Moreover, the correlation we found in this category was only slightly positive. The strongest correlation was found for venture capital-backed family firms. Maybe, venture capitalists use board representation to provide their portfolio firms with strategic competence. Unfortunately, the low number of firms in this category did not allow any significant results. A test on a larger sample would therefore be interesting. Overall, our results could be an indication that independent directors play a smaller role as catalysts for entrepreneurial activities than one could imagine considering their role as advisors (e.g. Forbes and Milliken, 1999; Huse, 1998). Maybe the role of independent board members for strategy is overestimated, however, this does not mean that they are of no use in change situations. Even though their existence is not associated with more extensive entrepreneurial activities they could be useful in making certain changes more successful. To test this, an evaluation of the change measures' effect on performance would be necessary. A further reason for the weak support we got for our hypotheses could be that independent directors are only one category of potential advisors among others. Firms that recognise a need for entrepreneurial activities, but for some reasons are reluctant to include independent board members, may instead use consultants to get help or establish ties to advisors in different ways. They can also, of course, get this support from employees at different levels and from members of the owner-family, or a wider social network (Johannisson, 2000). Moreover, they can set up an advisory council or have informal contacts to stakeholders who can provide them with useful information (Nordqvist and Melin, 2002). Research should therefore, not purely focus on boards as service providers, but include other actors, which may help the firm in carrying out entrepreneurial activities.

\section{The independent director concept}

As mentioned above, the secondary data we used for this article has restricted our possibilities to operationalise concepts such as independent directors. We thus chose a simple operationalisation, defining independent directors as board members who are neither employees nor members of the predominant owner family. In contrast to outside directors (who are not employees, but may be family members) this definition comprises a lesser share of those people who are strongly linked to the firm and cannot look at the company with unbiased eyes. The more independent directors are the easier should it be for them to bring radically new thoughts into the company. The question remains whether directors can have a close relationship to the firm that reduces their independence in other ways than those captured by our 
operationalisation. For instance, an external consultant who has co-operated with the company closely for a long time could be so much involved with the firm that he or she has problems in seeing the need for entrepreneurial activities. The emotional and even the economic relationship between the director and the firm could be so strong that the specific board member can no longer act in an independent way even if there is no employee or family relationship. In this respect a suitable definition could be the one proposed by Schwartz and Barnes (1991, p. 270). According to them an independent director is one who is neither a member of the controlling family, an active or retired employee, a retained professional advisor, nor a close family friend of the CEO's. Here, the independence of board members goes much farther than in our operationalisation. A deeper reflection on the issue of directors' independence is thus necessary though it goes beyond the scope of the present article.

\section{Conclusions and future research}

The present article enhances our understanding of board composition by studying the impact of different ownership structures on the ratio of independent directors. From the results, we may conclude that family firms are more reluctant to involve independent directors on their boards than non-family firms. Ownership by venture capitalists on the other hand increases the frequency of independent board members. These findings suggest that ownership have an impact on board roles. In family firms, boards often have a passive role, which is also indicated by the low frequency of board meetings in such firms. Hence, they are less used to link competent people to the company, at least not in a formal way. A reason for this could be family owners' reluctance to share control with independent directors. In venture capital-backed firms the board tends to be more active. Our results do not show what role the board has in such firms. However, the higher ratio of independent directors and the high frequency of meetings could be interpreted both as an indication of a stronger control role or of a stronger service role. The former would then be related to the venture capitalist's wish for controlling his/her investment through board representation. The latter could mean that independent directors are used to tie competencies to the firm that it does not possess on its own.

An interesting finding from the study is also that although the representation of independent directors on boards of venture capital-backed firms is significantly higher than in those with other ownership constellations, still many venture capital-backed firms do without independent directors. This somehow contrasts with the stereotype that venture capitalists will try to strengthen the monitoring function of the board by adding their own representatives. This finding opens up for further research. Do many venture capitalists take a relatively passive stance towards their portfolio firms and simply wait for them to develop or do they have other, maybe more informal, means to exercise control? Our findings suggest that independent directors are a relatively little used resource in firms with venture capitalist backing.

A limitation of our study is the relatively low number of venture capital backed firms in the sample. It is therefore, difficult to achieve significant results with respect to that category of firms. Concerning venture capital backed family firms that only represent a handful of cases we have not been able to draw statistically significant conclusions. A reason for the low number of venture capital backed firms in the sample is the relatively young and little developed venture capital industry in Sweden. Research on the influence of venture capitalists is probably easier to conduct in countries with a well-developed venture capital industry. In a Swedish context, similar research may be more successful in a couple of years, given that the industry will develop in the meantime. Sometimes, the use of relatively unsophisticated analysis tools, like the univariate statistics used in this article, is criticised. However, we argue that we so far only have rudimentary knowledge on the topic of our paper, especially with respect to family firms. Consequently, the univariate statistics used, provided us with knowledge that is novel and very much relevant to the understanding of the topic.

Our research brings up a number of questions for future research. From the discussion on board roles it would of course be interesting to see connections to the role of boards in entrepreneurial 
activities. Unfortunately, the present study has not generated any results that supported our hypothesised relationships between independent directors and entrepreneurial activities. One simple reason for this could be that the independent directors in our data set have not been board members long enough to have an impact on entrepreneurial activities. A follow-up study with more longitudinal data would therefore, be of interest. It could reveal if board members' influence on strategy requires more time or if their role as catalysts for change is simply overestimated in previous literature. Moreover, longitudinal data could allow to test in what direction independent directors and entrepreneurial activities are related, i.e. if independent directors induce higher entrepreneurial activities or the reverse.

Interesting suggestions for further research could be to use in-depth case studies to generate a deeper understanding of the processes inside the "black box", i.e. inside the actual board room (cf. Huse, 1998). This could also generate further knowledge on the role of board members in the strategy process, maybe resulting in more thoroughly grounded hypotheses used in the present study. One of the main contributions of this paper is that it examines the determinants of board composition in a Swedish context.

Further research could be directed across national comparisons as for instance how the role of venture capitalists varies between nations (Sapienza et al., 1996).

Finally, our findings also have a number of implications for practitioners. Family firms that choose to acquire additional capital should be aware that this is likely to result in a change of corporate governance practices. Handing over part of the ownership also means losing an element of control over the business. Although there are venture capitalists that do not insist on board representation, many external investors want to have board members that are independent of the owner family. While boards in many family firms are rather passive, having few meetings, owners have to be aware, that board activity will increase when letting new owners in. Although this means at least partial loss of control, an active board, involving members from outside the firm, may also be a good means to develop the firm. However, the lack of a clear connection between independent directors and entrepreneurial activities makes us doubtful concerning the contribution outsiders can make on the board. This issue clearly needs further research. Both from a policymaker's and a practitioner's perspective one should however be reluctant to over-emphasise the importance of independent directors for renewing a business. There may be alternative means to get an outsider's perspective and input to a firm's strategy.

\section{References}

Ang, J.S. (1991), "Small business uniqueness and the theory of financial management", The Journal of Small Business Finance, Vol. 1 No. 1, pp. 1-13.

Borch, O.J. and Huse, M. (1993), "Informal strategic networks and the board of directors", Entrepreneurship Theory and Practice, Vol. 18 No. 1, pp. 23-36.

Bruton, G., Fried, V. and Hisrich, R.D. (1997), "Venture capitalist and CEO dismissal", Entrepreneurship Theory and Practice, Vol. 21 No. 3, pp. 41-54.

Burgelman, R.A. (1983), "Corporate entrepreneurship and strategic management: insights from a process study", Management Science, Vol. 29 No. 12, pp. 1349-65.

Conger, J.A., Finegold, D. and Lawler, E.E. (1998), “Appraising boardroom performance”, Harvard Business Review, Vol. 76 No. 1, pp. 136-48.

Corbetta, G. and Tomaselli, S. (1996), "Boards of directors in Italian family businesses", Family Business Review, Vol. IX No. 4, pp. 403-21.

Covin, J.G. and Miles, M.P. (1999), "Corporate entrepreneurship and the pursuit of competitive advantage", Entrepreneurship Theory and Practice, Vol. 23 No. 3, pp. 47-63.

Covin, J.G. and Slevin, D.P. (1989), "Strategic management of small firms in hostile and benign environments", Strategic Management Journal, Vol. 10 No. 1, pp. 75-87.

Daily, C.M. and Dalton, D.R. (1993), "Boards of directors' leadership and structure: control and performance implications", Entrepreneurship Theory and Practice, Vol. 17 No. 3, pp. 65-81.

Danco, L.A. and Jonovic, D.J. (1981), Outside Directors in Family-Owned Businesses, University Press, Cleveland, $\mathrm{OH}$.

Dess, G.G., Lumpkin, G.T. and Covin, J.G. (1997), "Entrepreneurial strategy making and firm performance: tests of contingency and configurational modes", Strategic Management Journal, Vol. 18 No. 9, pp. 677-95. 
Dyer, W.G. Jr (1986), Cultural Change in Family Firms: Understanding and Managing Business and Family Transition, Jossey-Bass, San Francisco, CA.

Fiegener, M., Brown, M.K. and Derux, D.R. (2000), "CEO stakes and board composition in small private firms", Entrepreneurship Theory and Practice, Vol. 24 No. 4, pp. 5-25.

Forbes, D.P. and Milliken, F.J. (1999), "Cognition and corporate governance: understanding boards of directors as strategic decision-making groups", Academy of Management Review, Vol. 24 No. 3, pp. 489-505.

Ford, R.H. (1988), “Outside directors and the privately-owned firm: are they necessary?", Entrepreneurship Theory and Practice, Vol. 13 No. 1, pp. 49-57.

Fried, V.H., Bruton, G.D. and Hisrich, R.D. (1998), "Strategy and the board of directors in venture capital-backed firms", Journal of Business Venturing, Vol. 13 No. 6, pp. 493-503.

Gabrielsson, J. and Huse, M. (2002), "The venture capitalist and the board of directors in SMEs: roles and processes", Venture Capital, Vol. 4 No. 2, pp. 125-47.

Gabrielsson, J. and Winlund, H. (2000), "Boards of directors in small and medium-sized industrial firms: the importance of board member activity and working style on board task performance", Entrepreneurship and Regional Development, Vol. 12 No. 4, pp. 311-30.

Gersick, K.E., Davis, J.A., Hampton, M. and Landsberg, I. (1997), Generation to Generation - Life Cycles of the Family Business, Harvard Business School Press, Boston, MA.

Guth, W.D. and Ginsberg, A. (1990), “Guest editors' introduction: corporate entrepreneurship”, Strategic Management Journal, Vol. 11 No. 4, pp. 5-15.

Harris, T.B. (1989), "Some comments on family firm boards", Family Business Review, Vol. II No. 2, pp. 150-2.

Huse, M. (1995), Tante, barbar eller klan: om styrets rolle, Fagbokforlaget, Bergen.

Huse, M. (1998), "Researching the dynamics of board-stakeholder relations", Long Range Planning, Vol. 31 No. 2 , pp. $218-26$.

Huse, M. (2000), "Boards of directors in SMEs: a review and research agenda", Entrepreneurship \& Regional Development, Vol. 12 No. 4, pp. 271-90.

Jensen, M.C. and Meckling, W.H. (1976), "Theory of the firm: managerial behavior, agency costs and ownership structure", Journal of Financial Economics, Vol. 3 No. 4, pp. 82-137.

Johannisson, B. (2000), "Networking and entrepreneurial growth", in Sexton, D.L. and Landström, H. (Eds), The Blackwell Handbook of Entrepreneurship, Blackwell, Oxford.

Johannisson, B. and Huse, M. (2000), "Recruiting outside board members in the small family business: an ideological challenge", Entrepreneurship and Regional Development, Vol. 12 No. 4, pp. 353-78.

Johnson, G. (1988), "Rethinking incrementalism", Strategic Management Journal, Vol. 9 No. 1, pp. 75-91.

Johnson, R.A., Hoskisson, R.E. and Hitt, M.A. (1993), "Board of director involvement in restructuring: the effects of board versus managerial controls and characteristics", Strategic Management Journal, Vol. 14 No. 4, pp. 33-50.

Jonnergård, K. and Svensson, C. (1995), "Corporate board behavior: emphasis in role fulfilment - a typology", Corporate Governance - An International Review, Vol. 3 No. 2, pp. 65-71.

Jonovic, D.J. (1989), "Outside review in a wider context: an alternative to the classic board", Family Business Review, Vol. II No. 2, pp. 125-40.

Larsson, L.T. and Melin, L. (1999), "The board of directors driving Swedish SMEs forward: some observations from a non-executive director perspective", paper presented at the $2^{\text {nd }}$ International Conference on Corporate Governance and Direction, Henley Management College, UK.

Lerner, J. (1995), "Venture capitalists and the oversight of private firms", The Journal of Finance, Vol. 50 No. 1, pp. 301-19.

Lumpkin, G.T. and Dess, G.G. (1996), "Clarifying the entrepreneurial orientation construction and linking it to performance”, Academy of Management Review, Vol. 21 No. 1, pp. 135-72.

Mace, M.L. (1971), Directors: Myth and Reality, Harvard University, Boston, MA.

Mason, C. and Harrison, R. (1999), "Editorial - venture capital: rationale, aims and scope", Venture Capital, Vol. 1 No. 1, pp. 1-46.

Miles, R. and Snow, C. (1978), Organisational Strategy, Structure and Process, McGraw-Hill, New

York, NY.

Mueller, R.K. (1988), "Differential directorship: special sensitivities and roles for serving on the family business board", Family Business Review, Vol. 1 No. 3, pp. 239-48.

Neubauer, F. and Lank, A.G. (1998), The Family Business - its Governance for Sustainability, Macmillan Business, London.

Nordqvist, M. and Melin, L. (2002), "The dynamics of family firms: an institutional perspective on corporate governance and strategic change", in Fletcher, D. (Ed.), Understanding the Small Family Business, Small Business Series, Routledge, London.

Pearce, J.A. and Zahra, S.A. (1991), "The relative power of CEOs and boards of directors: associations with corporate performance", Strategic Management Journal, Vol. 12 No. 2, pp. 153-235.

Pettigrew, A. and Whipp, R. (1991), Managing Change for Competitive Success, Blackwell, Oxford.

Pfeffer, J. and Salancik, G.R. (1978), The External Control of Organisations: A Resource Dependence Perspective, Harper \& Row, New York, NY.

Rosenstein, J. (1988), "The board of strategy: venture capital and high technology", Journal of Business Venturing, Vol. 3 No. 2, pp. 159-71.

Rosenstein, J., Bruno, A.V., Bygrave, W.D. and Taylor, N.Y. (1993), "The CEO, venture capitalists, and the board", Journal of Business Venturing, Vol. 8 No. 2, pp. 99-114. 
Samuelsson, M. (1999), "Swedish family and non-family enterprises: demographic and performance contrasts", JIBS Research Report No. 1999-3, Jönköping International Business School, Jönköping.

Sapienza, H.J., Manigart, S. and Vermeir, W. (1996), "Venture capitalist governance and value added in four countries", Journal of Business Venturing, Vol. 11 No. 6, pp. 439-69.

Schumpeter, J.A. (1934), The Theory of Economic Development, Transaction Publishers, New Brunswick, NJ.

Schwartz, M.A. and Barnes, L.B. (1991), "Outside boards and family businesses: another look", Family Business Review, Vol. IV No. 3, pp. 268-85.

Shane, S. and Venkataraman, S. (2000), "The promise of entrepreneurship as a field of research", Academy of Management Review, Vol. 25 No. 1, pp. 217-26.

Stevenson, H.H. and Gumpert, D.E. (1985), "The heart of entrepreneurship", Harvard Business Review, Vol. 64 No. 2, pp. 85-94.

Stevenson, H. and Jarillo, J.C. (1990), “A paradigm of entrepreneurship: entrepreneurial management”, Strategic Management Journal, Vol. 11 No. 4, pp. 17-27.

Stopford, J.M. and Baden-Fuller, C.W.F. (1994), "Creating corporate entrepreneurship”, Strategic Management Journal, Vol. 15 No. 7, pp. 521-36.

Ward, J.L. (1988), “The active board with outside directors and family firm”, Family Business Review, Vol. I No. 3 , pp. 223-30.

Ward, J.L. (1991), Creating Effective Board for Private Enterprises, Jossey-Bass, San Francisco, CA.

Ward, J.L. and Handy, J.L. (1988), “A survey of board practices”, Family Business Review, Vol. I No. 3, pp. 289308.

Westhead, P. and Cowling, M. (1999), "Family firm research: the need for a methodological rethink", Entrepreneurship Theory and Practice, Vol. 23 No. 1, pp. 31-56.

Westhead, P., Cowling, M. and Storey, D. (1996), "The management and performance of unquoted family companies in the United Kingdom", Centre for Small and Medium-sized Enterprises, Working paper No. 42, The University of Warwick, Coventry.

Whisler, T.L. (1988), "The role of the board in the threshold firm", Family Business Review, Vol. I No. 3, pp. 309-21.

Zahra, S.A. and Pearce, J.A. (1989), "Boards of directors and corporate financial performance: a review and integrative model", Journal of Management, Vol. 15 No. 2, pp. 291-334.

Zider, B. (1998), "How venture capital works", Harvard Business Review, Vol. 76 No. 6, pp. 131-9. 